\title{
The Indian Corporate Board Efficiency and its Impact on Financial Performance
}

\author{
Mohd Sarim ${ }^{a}$ \\ ${ }^{a}$ Institute of Business Management, GLA University, Mathura, India. \\ E-mail: mohd.sarim@gla.ac.in
}

Article History: Received: 11 January 2021; Accepted: 27 February 2021; Published online: 5 April 2021

\begin{abstract}
The objective of the study is to explore the board characteristics and its impact on the financial performance of Indian companies. The sample comprises of top 100 companies listed on the Bombay Stock Exchange for the financial year 20182019. The data required for the analysis was collected from the annual reports of the companies available at their respective websites and from the Prowess database of the Centre for Monitoring of Indian Economy. The paper constructed sub-indices for the board as board composition index, board independence index and board disclosure index. Combining all sub-indices, we formed the Board Composite Index. Further, the data was analysed to draw meaningful conclusions. Firm size is used as a controlling variable. The results show that there is a strong relationship between board indicators and return on asset.
\end{abstract}

Keywords: Corporate Governance, Board Indicators, Return on Assets.

\section{Introduction}

The financial performance of companies is largely affected by the corporate governance characteristics which in the recent past has invited the due attention of the researchers to explore the performance of companies as a relationship with corporate governance characteristics. The corporate governance plays an important in monitoring the affairs of the company. Financial misappropriation due to weak of governance structure and mechanism hampers the trust of the shareholders. Therefore, a good corporate governance mechanism is required to curb the unfair practices. Thus, abnormalities in financial system may be prevented. (Smaili et al., 2016).

\section{Literature Review}

Corporate governance issues in India are distinct from the Anglo Saxon system (Varma 1997). In India, the problem at centre lies at disciplining dominating shareholders and protecting minority shareholders (Pande and Ansari 2013). Board structure and processes, independence of directors, related party transaction and nature of dominating shareholders are specific to Indian firms. A good governance system is important for safeguarding against risk of misappropriation of fund by ensuring transparency and accountability (Claessens, 2006; Khiari, 2007). The current financial market system has created a separation in the ownership and control mechanism of a public limited company due to which an agency problem arises. Shareholders invest their hard earned money and are the real owners of the organization. Managers, though do not invest in the equity of the firm but are entrusted with the task of managing the resources of the organization (Andersen, 2017). This gap between the ownership of resources and the management of resources is the main reason behind all agency issues (Ross, 1973; Jensen and Meckling, 1976).

The relationship between the shareholders and the managers is often referred to as principal-agent relationship. The shareholders may expect a higher return on their investment but the managers may look for other objectives of the organisation such as expansion and diversification of business. Such differences in the motives of the shareholders and the managers may lead to a higher agency cost and eventually may reduce the wealth of shareholders. Also, mismanagement of resources may take place and managers may take decisions that are not favourable to shareholders (Grossman and Hart, 1986). This varied interest of shareholders and managers results in a behaviour where both the parties try to control each other. This controlling behaviour of the principal and the agent requires some mediation mechanism to monitor the interest of both of the principal and the agent. One of the best mechanisms to mediate the interest of the principal and the agent is a board of directors which plays a critical and acts as stewards of particular interest group.

Being steward of a particular interest group, the directors act as guardian of the assets of the company (Donaldson and Davis, 1991). The directors are motivated to perform their jobs perfectly because they are ambitious to achieve recognition. The board of directors are entrusted with the task of monitoring and controlling the managers and try to prevent the unscrupulous conduct of the managers. Thus, safeguarding the interest of the shareholders and other stakeholders of the organisation (Fama and Jensen, 1983).

The managers present the affairs of a company through annual reports on a yearly basis. The directors assess the performance of the managers through the evaluation of the annual reports. To ensure the authenticity of the facts and figures mentioned in the annual report the board of the directors appoint an audit committee. The audit committee appoints auditors who verify the genuineness of financial report. Thus, the board is a crucial mechanism 
that acts as bridge between the stakeholders and the managers and try to minimise agency issues (Mishra and Mohanty, 2014).

Human beings have opportunistic behaviour and may conceal material information or may undertake actions and decisions not favourable to shareholders (Windolph and Moeller, 2012). In worst of the situations such decisions may lead to financial irregularities. The mangers being the agents of the shareholders have some prespecified goals and objectives which they may not pursue in order to fulfil their own interest. The role of directors is crucial in such situations to protect the interest of the investors.

The internal corporate governance through the mechanism of board of directors is examined on factors such as the structure of the board, separate chairman, number of board meetings, board educational level, presence of nomination committee, presence of female board member and so on (Hodgson, 2011). Governance through the mechanism of an independent board of directors (board free from management's control) should be able to provide guidance, effective monitoring of management, improved decisions and aligning the interest of all the stakeholders (Aguilera and Desender, 2012; Bhagat and Bolton, 2006). Bhagat and Bolton (2006) considered board independence and ownership as a good proxy for corporate governance which is a must for protecting the interest of minority shareholders. The best practices of governance tend to focus critically on these key factors. One of the most critical questions associated with structure of the board is related with the "independence" of the board and has been the emphasis of most of the corporate governance reforms across the world (Manna et al., 2016). Directors are classified as being "unrelated and related", "independent and non- independent" or "executive and nonexecutive". The classification is based upon the degree of independence vested upon the director. The independence of the board can be determined with respect to the ratio of the executive to non-executive directors.

\section{Methodology}

The research is based on secondary data. The data for BSE 100 index companies for the financial year 20182019 was collected, processed and analysed. The data required constructing corporate board characteristics index and other sub-indices were obtained from the annual reports of the companies. Data for financial performance is obtained from the Prowess database of Centre for Monitoring of Indian Economy (CMIE).

\section{Objectives}

The paper aimed at exploring the characteristics of Indian corporate board. Further the paper measure the impact of the same on performance of companies.

\section{Hypothesis}

For measuring the impact of board index on performance the paper tested the hypotheses - There is no significant influence of board index/board sub-indices on performance (return on asset) of companies.

\section{Board Index}

The impact of the board characteristics on the financial performance of companies is measured by constructing different indices for board as board composition, board independence and board disclosures. Combining all subindices we formed the Board Index.

\section{Board Composition Index (BCI)}

Board composition index is formed with factors (i) presence of nominee directors; (ii) presence of female director on board; (iii) CEO is not the chairman.

\section{Board Independence Index (BII)}

The board independence index is composed of (i) board consists of at least fifty percent independent directors; (ii) Totally independent audit committee; (iii) totally independent investors' Grievance committee; (iv) totally independent nomination and remuneration committee.

\section{Board Disclosure Index (BDI)}

The board disclosure index included disclosures on (i) significant related party transactions; (ii) significant changes in accounting policies influencing sales and profits; (iii) presence of director is indicated in the AGM. 


\section{Performance Variable}

There are a number of studies conducted on the relationship between corporate governance and financial performance of companies but the results are unclear with respect to the influence of corporate governance parameters on the performance of the Indian companies. The researchers have used varied parameters for measuring the financial performance of companies. The financial performance can be measured from accounting as well as market point of view. Pande and Ansari (2013) measured financial performance of companies by using return on assets which is an accounting based financial performance measure that reflects the wealth effect.

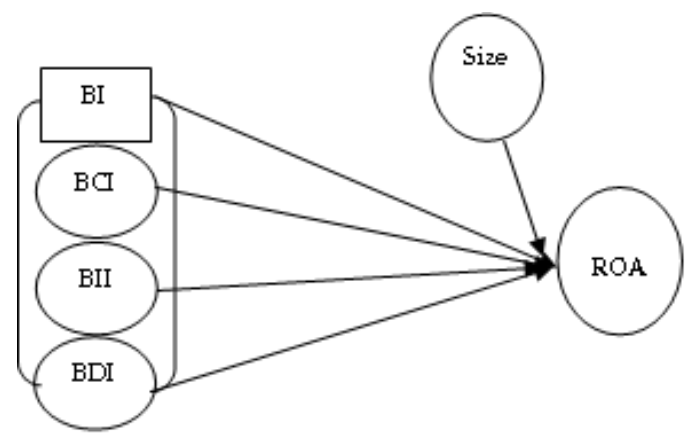

Figure 1. Conceptual Model

\section{Control Variable}

The performance of a company is generally affected by the size of its assets or market capitalization (Fama and French, 1992). Therefore, size of the firm measured in terms of market capitalization is used as a control variable for data analysis. The proposed model for the study is depicted in Figure 1.

Table 1. Descriptive Statistics and Correlation Among Variable

\begin{tabular}{lllllllll}
\hline Variables & Mean & SD & ROA & Size & BCI & BII & BDI & BI \\
\hline ROA & 0.28 & 0.22 & 1 & $0.17 *$ & 0.05 & $0.17 *$ & $0.37 * * *$ & $0.35^{* * *}$ \\
Size & 7.03 & 2.36 & & 1 & $-0.22^{* *}$ & $-0.27 * * *$ & $0.44^{* * *}$ & -0.21 \\
BCI & 1.77 & 0.83 & & & 1 & 0.14 & -0.04 & $0.38^{* * *}$ \\
BII & 6.23 & 1.33 & & & & 1 & $0.16^{*}$ & $0.76^{* * *}$ \\
BDI & 0.47 & 0.93 & & & & & 1 & $0.56^{* * *}$ \\
BI & 8.61 & 1.98 & & & & 1 \\
\hline \multicolumn{7}{l}{ Note: $* \mathrm{p}<0.10 ; * \mathrm{p}<0.05 ; * * \mathrm{p}<0.01 ; \mathrm{N}=98$} & &
\end{tabular}

Table 2. Regression Results

\begin{tabular}{lllllll}
\hline $\begin{array}{c}\text { Dependent } \\
\text { Variable }\end{array}$ & Model & $\begin{array}{c}\text { Independent } \\
\text { Variable }\end{array}$ & $\begin{array}{c}\text { Coefficien } \\
\mathbf{t}\end{array}$ & $\begin{array}{c}\text { Standar } \\
\text { d error }\end{array}$ & $\begin{array}{c}\text { Coefficient of } \\
\text { determinatio } \\
\mathbf{n}\end{array}$ & F-Stats \\
\hline ROA & 1 & Constant & 0.16 & 0.04 & & \\
\multirow{2}{*}{ ROA } & 2 & Size & $0.02^{*}$ & 0.02 & 0.03 & 4.15 \\
& & Constant & $(-) 0.02$ & 0.11 & & $4.06 * * *$ \\
& Size & 0.01 & 0.02 & 0.01 & \\
\hline & BCI & 0.03 & 0.01 & & \\
\hline & BII & $0.03^{*}$ & 0.03 & & \\
\hline
\end{tabular}

Note: $* \mathrm{p}<0.10 ; * * \mathrm{p}<0.05 ; * * * \mathrm{p}<0.01$

\section{Results}


The correlations result for dependent variable, independent variables and control variable is presented in Table 1. According to the correlation results, except the board composition index, the remaining two indices - board independence and board disclosure indices are significantly related with the return on asset. Similarly, the board composite index measure is significantly correlated with the return on asset.

Further, regression analysis was applied to confirm our correlation results (Table 2). In the first model firm size was entered as independent variable which came out to be positively and significantly affecting the ROA. In the next model, when the board composition, board independence and board disclosure indices are entered, board independence and board disclosure indices are positively and significantly influenced the accounting performance of Indian companies. Results support that there is a significant and positive relationship of board independence index and board disclosure index with the return on asset, while board composition index is not significantly impacting the accounting performance of the Indian companies.

\section{Conclusions}

The study constructed board index on the basis of composition, independence and disclosure aspects of Indian boards. The strong influence of the independence and disclosure on the financial performance of Indian companies call for the creation of strong and independent committees and disclosure regulations. A positive relation between the board index and return on asset suggest that Indian companies should follow better governance practices in order to boost up the confidence of investors and other stockholders.

\section{References}

6. Andersen, J.A. (2017). The concept of managerial discretion in corporate governance - better off without it?, Corporate Governance: The international journal of business in society, 17(3), 574-587.

7. Aguilera, R.V., \& Desender, K.A. (2012). Challenges in the Measuring of Comparative Corporate Governance: A Review of the Main Indices. Research Methodology in Strategy and Management, 7.

8. Bhagat, S., \& Bolton, B. (2006). Board ownership and corporate governance indices. Unpublished University of Colorado at Boulder.

9. Claessens, S. (2006). Corporate governance and development. World Bank Research Observer, 21(1), 91-122.

10. Donaldson, L., \& Davis, J.H. (1991). Stewardship theory or agency theory: CEO governance and shareholder returns. Australian Journal of management, 16(1), 49-64.

11. Fama, E.F., \& Jensen, M.C. (1983). Separation of ownership and control. Journal of law and economics, 301-325.

12. Grossman, S.J., \& Hart, O.D. (1986). The costs and benefits of ownership: A theory of vertical and lateral integration. Journal of Political Economy 94(4), 691-719.

13. Hodgson, A, Lhaopadchan, S., \& Buakes, S. (2011). How informative is the Thai corporate governance index? A financial approach. International Journal of Accounting and Information Management, 19(1), 53-79.

14. Jensen, M.C., \& Meckling, W.H. (1976). Theory of the firm: Managerial behavior, agency costs and ownership structure. Journal of financial economics, 3(4), 305-360.

15. Khiari, W., Karaa, A., \& Omri, A. (2007). Corporate governance efficiency: an indexing approach using the stochastic frontier analysis. Corporate Governance, 7(2), 148-161.

16. Manna, A, Sahu, T.N., \& Gupta, A. (2016). Impact of Ownership Structure and Board Composition on Corporate Performance in Indian Companies, Indian Journal of Corporate Governance, 9(1), 44-66.

17. Mishra, S., \& Mohanty, P. (2014). Corporate governance as a value driver for firm performance: evidence from India. Corporate Governance, 14(2), 265-280.

18. Pande, S., \& Ansari, V.A. (2013). Effectiveness of Independent Directors on the Boards of Indian Listed Companies - Are the Recent Regulatory Changes Enough?.

19. Ross, S.A. (1973). The economic theory of agency: The principal's problem. The American economic review, 63(2), 134-139.

20. Smaili, N., \& Labelle, R. (2016). Corporate governance and accounting irregularities: Canadian evidence. Journal of Management \& Governance, 20(3), 625-653.

21. Varma, J.R. (1997). Corporate governance in India: Disciplining the dominant shareholder. IIMB Management Review, 9(4), 5-18.

22. Windolph, M., \& Moeller, K. (2012). Open-book accounting: Reason for failure of inter-firm cooperation? Management Accounting Research, 23(1), 47-60. 